\title{
sciendo
}

CIVIL AND ENVIRONMENTAL ENGINEERING REPORTS

E-ISSN 2450-8594

CEER 2019; 29 (3): 183-199

DOI: $10.2478 /$ ceer-2019-0034

Original Research Article

\section{NEW DATINGS OF DEPOSITS FROM ODRA RIVER VALLEY - STRATIGRAPHIC CONSEQUENCES AND INTERPRETATION AT FLUVIAL SUCCESSION}

\author{
Agnieszka Helena GONTASZEWSKA-PIEKARZ ${ }^{1}$, \\ Małgorzata SZCZEPANIAK ${ }^{2}$ \\ ${ }^{1}$ University of Zielona Gora, Zielona Góra, Poland \\ ${ }^{2}$ Adam Mickiewicz University, Poznań, Poland
}

\begin{abstract}
This paper presents organic sediments age analysis in Odra river valley in Słubice, western Poland. In this middle reach of Odra valley reach the uppermost fluvial deposits contain several alternate layers of organic sediments. These deposits have been mostly interpreted as the Holocene fluvial (floodplain) sediments, even if visible admixture of organic matter is not observed. However, there is also another hypothesis. Geotechnical studies conducted in several locations in Słubice, have questioned this interpretation. The main argument was the values of preconsolidation ratio in the range of 0.8 to 5.4 , which may suggest, that the analysed sediments were covered by an ice sheet. Also, based on the presence of a clay layer devoid of organic matter impurities in the top of organic deposits, the second one presumes an interglacial (possibly Eemian) age of the discussed fluvial/organic sediments (peats and silts). To verify these hypotheses, six samples from six different boreholes drilled in the Odra river valley, in the centre of Słubice were collected. The results of ${ }^{14} \mathrm{C}$ dating and its interpretation allowed to determine the age of the tested material. All analysed samples from Stubice (Odra river valley) were formed within the last 10,000 years - in Preboreal, Atlantic and Subboreal. Such a result contradicts the earlier stratigraphic interpretations.
\end{abstract}

2 Corresponding author: Adam Mickiewicz University, Institute of Geology, Bogumiła Krygowskiego st. 12, 61-680 Poznań, Poland, e-mail: malgorzata.szczepaniak@amu.edu.pl, tel. +48618296004 . 
Keywords: alluvial deposits, radiocarbon dating, Holocene, Słubice, Odra river valley

\section{INTRODUCTION}

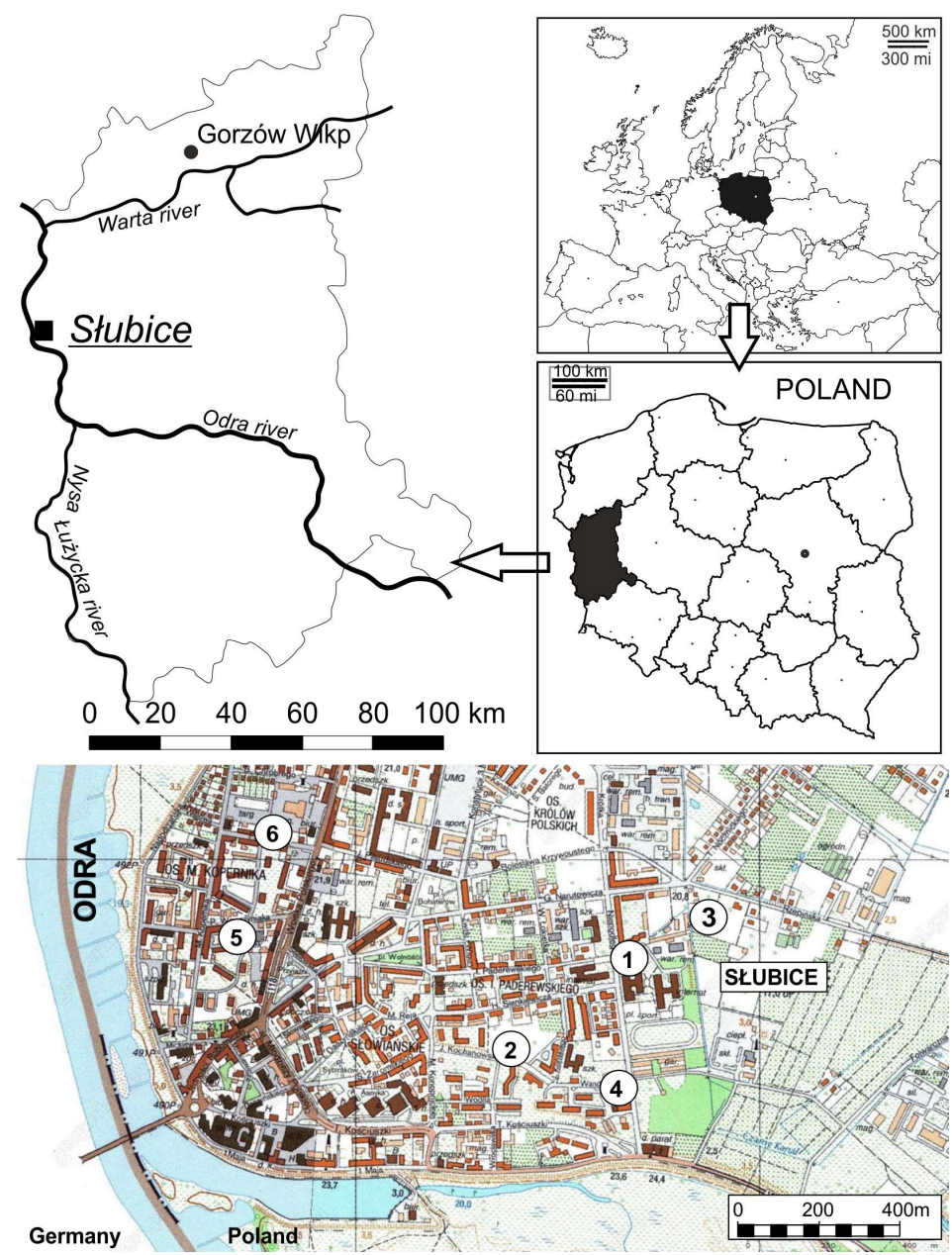

Fig. 1. Location of Słubice area (A) and boreholes with sample points (B) in Słubice, Odra river valley (map B from geoportal.gov.pl, access 27.01.2017)

Frequent investigations of the shallow subsoil ( $\sim 10 \mathrm{~m}$ below ground level) for construction needs in Słubice (Odra river valley), revealed several layers of sand, gravel and typical organic sediments (peats) and silty-clayey layers mixed with varying contents of organic matter (alluviums). The fluvial systems are very sensitive to environmental changes and in Pleistocene and Holocene in central Europe especially climatic changes were very dynamic. This is the reason that 
thickness of the analysed deposits was varied. Due to the Słubice location (in the weakly meandering Odra river valley), the sediments (according first hypothesis) are most frequently identified as Holocene fluvial mud soils ([36] floodplain facies sediments) even without a distinctly visible organic matter. It should be noted that in Stubice area in fluvial sediments there is no radiometric dating or palynological evidence confirming these assumptions [36]. Geotechnical investigations performed in several locations shed doubts upon this interpretation, which was described in details by Kotowski and Kraiński [18, 19]. The authors found a silty layer without any admixtures of organic matter in the ceiling of organic sediments. They interpreted this layer as a glacial-limnic sediments (icedammed silt). Next (based on the geotechnical properties of the sediments and their depth and thickness) they proposed a hypothesis of a possible interglacial origin of the organic sediments situated below (the second hypothesis in that paper - Pleistocene age of the deposits).

However the floodplain sediments in river valleys can consist fine-grained (silty and clay) and also sandy and thicker sediments [40] and also even in a young floodplain sediments they can be characterized by different thickness and depth $[14,15]$. Taking into account very dynamic climatic changes in Pleistocene in Europe and a couple of fluvial periods in Holocene, without radiometric dates or other environmental (i.e. palynological) evidence there is no possibility to conclude about the age of the mentioned sediments in Odra river valley in Stubice $[15,30,32,34]$.

Thus, the literature and other technical studies report two different interpretations as to the age of the formations. It was the reason for undertaking an attempt of final solution of organic sediments age problems based on radiocarbon dating.

\section{REGIONAL SETTING AND GEOLOGICAL BACKGROUND}

Stubice is located on the Odra river valley (Fig. 1) i.e. vast majority of the town area (the centre including; on the area of Lubusz breakthrough of the Odra river) and the Lubusz Upland plain (its most eastern part), which is separated from the Odra river valley with a distinct morphological edge (to be more specific - on the area of Torzym plain; 22).

The Odra Valley itself (where Stubice is located) is of a strict erosive nature.

In the basement of the town, Miocene sediments are found. These sediments are glacitectonically deformed (the so called "Stubice Arc"). The Arc is continued on German territory $[16,17]$. The deformations are not visible in the morphology of the area. The Miocene roof in the centre of Stubice is situated at approximately $70 \mathrm{~m}$ a.s.l. [17], or $30 \mathrm{~m}$ a.s.l. - according to a detailed geological map of Poland (1:50000), sheet Stubice [36], whereas on the German side - outcrops of lignite 
are found on the surface of the ground. According to Urbański and Winter [37], sands and tills of San glaciation analysed $15 \mathrm{~km}$ north-east of Stubice are glaciotectonically deformed too.

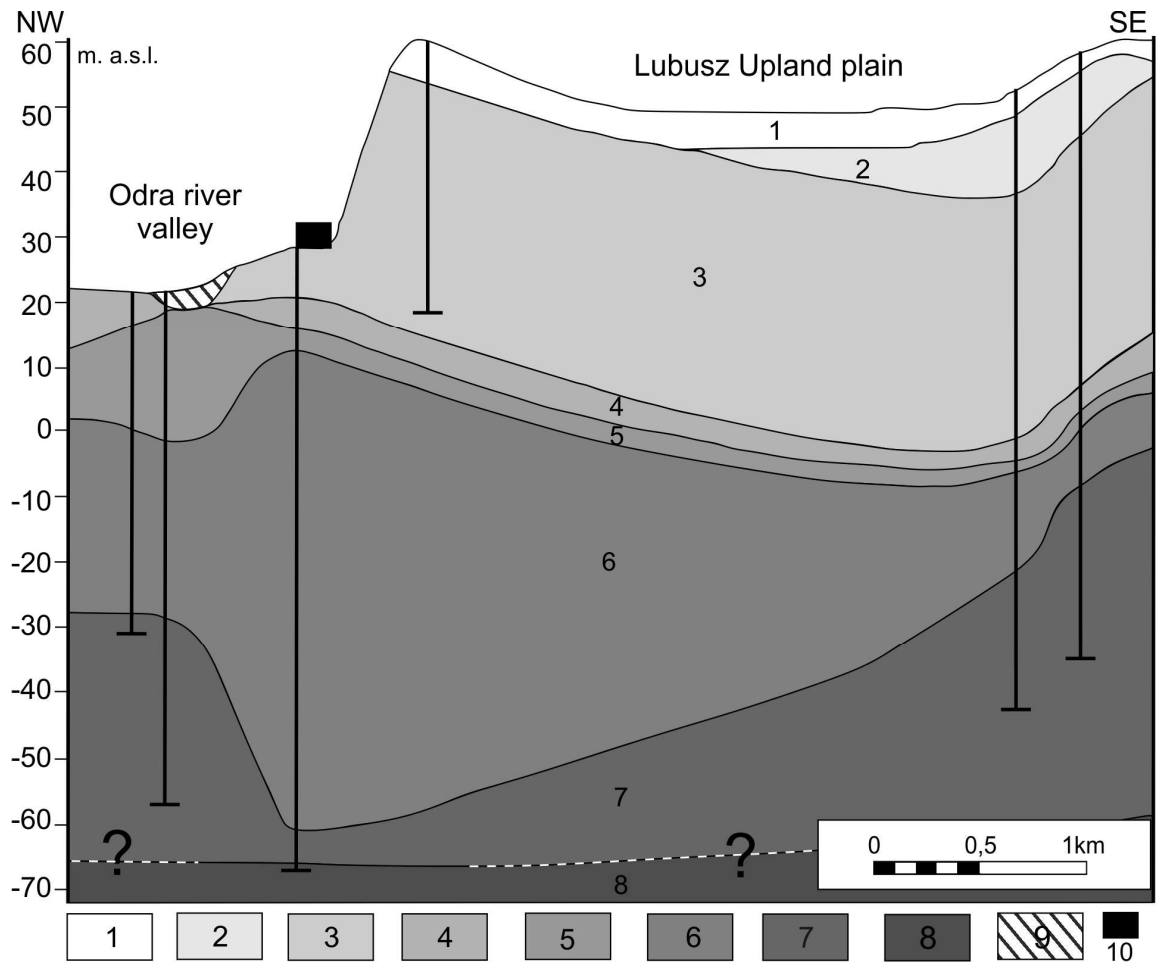

Fig. 2. Geological background of Słubice region according to Kotowski and Kraiński

[18], changed and simplified; Explanations: 1 - sands of Vistulian glaciation;

2 - tills of Poznań phase of Vistulian glaciation; 3 - interstadial sands; 4 - tills of Leszno (Brandenburg) glaciation; 5 - sands of Eemian interglaciation; 6-tills of Odranian and Warthanian glaciation with interbeddings of sands and clays; 7 - sands of Mazovian interglaciation; 8 - Miocene, 9 - anthropogenic soils, 10 - sampling points, ? unknown

Kotowski and Kraiński [18] claimed that over deformed Miocene sediments lay sands of the Mazovian (Holsteinian) interglaciation. Tills of Odranian and Wartanian glaciation are upper-lying sediments. They are local bipartite (Fig. 2). Above them sands of Eemian interglaciation origin were identified, with peat and alluvium interbeddings. The thickness of this interglacial deposits ranges from several to a dozen of metres. Above that, there are tills and sands of Vistulian glaciation (Leszno (Brandenburg) and Poznan phase, on the area of the upland plain exclusively), as well as Holocene sediments, related to the Odra river. 


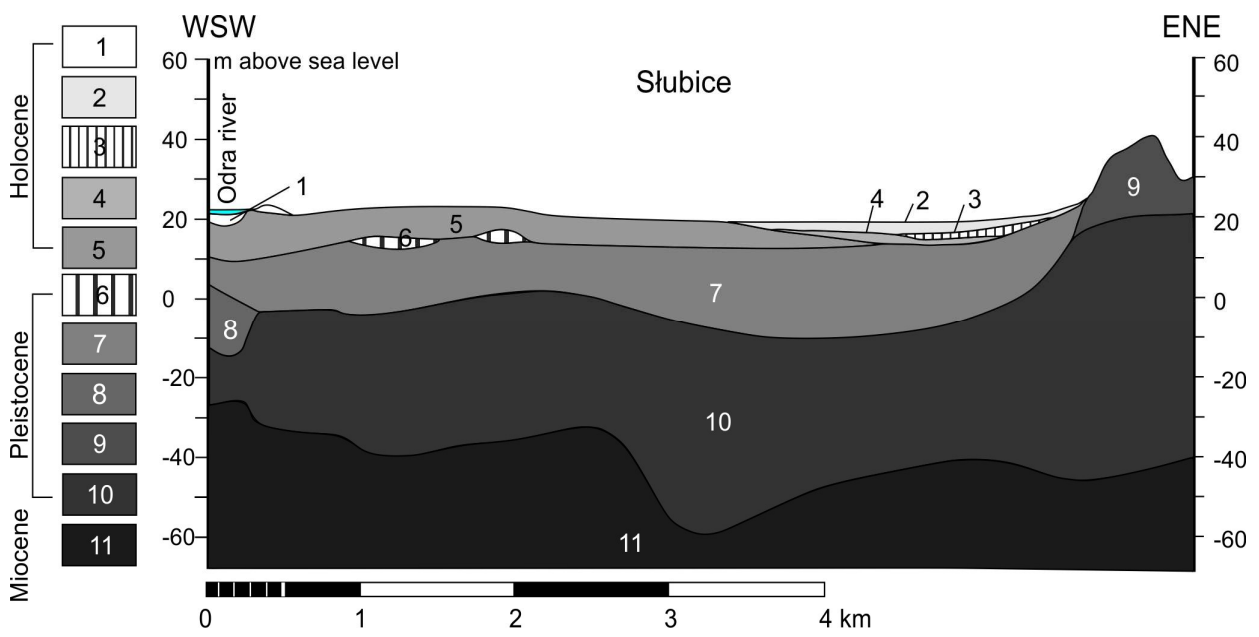

Fig. 3. Geological background of Słubice region according to Urbański [36], changed and simplified. Explanations: 1 - fluvial sands and gravels (river bottom valley),

2 - fluvisoils; 3 - peats, 4 - limnic silts and clays; 5 - fluvial sands and gravels - flood terrace (floodplain) , 6 - peats; 7 - fluvial sands and gravels - overflood terrace;

8 - limnic silts and silty sands; 9 - glaciofluvial sands and gravels; 10 - tills of San 1 (Elsterian) glaciation; 11 - clays, silts, sands, lignite

Urbański's interpretation [36] is different. He claims that the tills overlying the Miocene sediments belong to San I glaciation. The tills are covered by sandy sediments connected to the Vistulian glaciation, and locally also by silts of Eemian glaciation. Pleistocene sediments are covered by river sediments of Holocene origin, about $10 \mathrm{~m}$ thick (Fig. 3).

The whole area was repeatedly covered by glaciations, and due to the type of sediments and glaciotectonics, the geological structure of the whole region is complicated $[24,36]$.

\section{PREVIOUS VIEWS ON GEOLOGY OF SLUBICE REGION}

Among the surface sediments on the investigated area, fluvial sediments of the Odra river are prevailing (deposits which infills oxbow lakes and flood basins). Due to the location of Stubice in a large river valley, these deposits are mostly interpreted as the Holocene floodplain facies, even if visible admixture of organic matter is not observed.

However, the stratigraphic interpretations of the sediments are different. Most of the shallow geological structure data comes from the geotechnical drilling. The fluvial sediments are described there as a peat, mud or silty clay. Kotowski and Kraiński [18] hypothesized that silty clay can be interpreted as a glaciolimnic 
sediments. The consequence of this is to recognize underlying organic sediments (peat and alluvium) as interglacial ones. Similar sediments were documented in Radówko (few kilometres from the town, NE from Słubice). In this area, the presumed pre-Holocene age of sediments was confirmed by palynological data [37] the Upper Wartanian Glaciation, the Eemian Interglacial and the Early Vistulian Glaciation. Gontaszewska [10,11] also assumed a presence of remnant in the Słubice area, which is built by the older sediments that leaned against erosional activity of the Odra river. Also, the analysis of geological-engineering parameters of the mentioned non-organic sediments indicate that the organic sediments formerly described as fluvial are older than Holocene [19, 20]. One of them was the value of the preconsolidation ratio in the range of 0.8 to 5.4, which may suggest that in the past the analysed sediments were covered by an ice sheet [3]. Additionally, the matter composing the peats and the underlying alluviums is well decomposed. On this basis, Kotowski and Kraiński [18] assumed that a part of the silty and clayey sediments from the Stubice area to be of glaciolimnic nature. Visible lamination and low organic matter content could be also an evidence for this hypothesis. However, fluvisol (genetically young soil in fluvial deposits) can also be characterized by lamination and low organic matter content. Interpretations relating the age of the peats which were bored in Odra river Valley at the depths of 6 to $10 \mathrm{~m}$ (11.0 to $15.0 \mathrm{~m}$ a.s.1.) are based on the analogous sediments found in the area of Frankfurt am Oder, where the same sediments were bored in the Odra river Valley at similar depths. The radiocarbon age of the sediments was established at $11,840 \pm 70$ BP [4]. Therefore, Urbański [36] considered peat from Stubice as the same age. This age may correspond to the warm and moist global interstadial - Allerød at the end of the last glacial period. The use of such analogy may by misleading in this case. Bearing in mind the meandering character of a river, sediments similar in lithology may be formed within a valley throughout the period of thousands of years (Odra oxbow lakes on the same area and the same level can be of different ages - as a results of a long term sedimentation over a thousands of years).

The above doubts and significant differences in interpretation of the sediments age described in Odra river Valley in Stubice contributed to the decision of further research related to the determination of their radiometric age.

\section{MATERIAL AND METHODS}

From over a dozen of accessible and described by author soil profiles in the Odra river valley, six different profiles were selected for probing and dating. The location of the boreholes was shown on the Figure $1 \mathrm{~B}$. The sampling areas had been geotechnically investigated earlier by the authors. Also Kotowski and Kraiński $[18,19]$ analysed similar sediments form Słubice area. The investigation 
was performed for engineering design purpose, and their profile was marked in details (Fig. 4). The authors assumed that all six selected profiles had to fulfilled one condition: more than one layer of the organic sediments (peats or alluvium) had to occur in the profile.

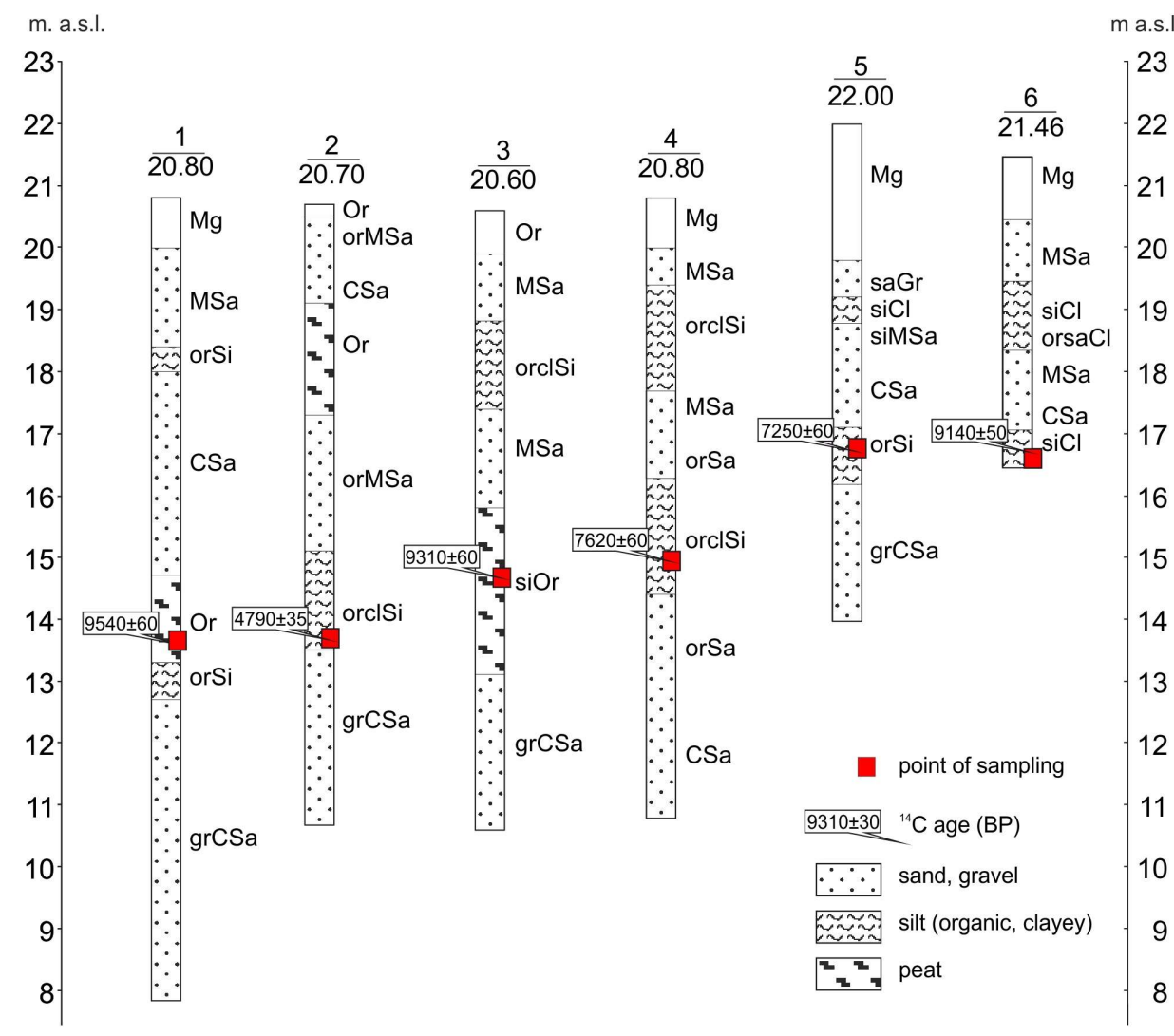

Fig. 4. Simplified profiles of the six boreholes with marked type of soils [according to 31] and depth of the radiocarbon dated samples (Słubice 1 to 6).

Soil fraction: $\mathrm{Gr}$ - gravel, $\mathrm{Sa}$ - sand, $\mathrm{Si}$ - silt, $\mathrm{Cl}$ - clay, $\mathrm{Or}$ - organic, $\mathrm{Mg}$ - anthropogenic soil

The drillings were performed with a hammer probing, with $60 \mathrm{~mm}$ diameter. The samples were taken from the deepest layers of the known organic sediments (depth of 5 to $7 \mathrm{~m}$ below ground level). Samples derived from the central part of the organic layer of each analysed stem were subject to the analysis in order to avoid contamination. A $1 \mathrm{~cm}^{3}$ sample was cut out in such a way that the edge of the stem was not taken to the analysis, to protect the sample from containing 
sediments from overlying layers which could influence proper dating. The tested samples did not reveal any organic samples, which could be macroscopic observed (except peats), and the sediment was homogeneous. The samples were described according to Polish Standards PN-EN ISO 14688 [31] on the names for soils. The authors assumed that the searched dates should not determine the beginning or the end of sedimentation but should allow whether the sediments are of Holocene origin or whether they come from the last interglaciation and thus should be treated as of Pleistocene origin. The profiles of the performed boreholes are shown in Figure 4 and Table 1.

All sediments in the selected six profiles were analysed by using standard macroscopic methods (visual and manual techniques) in a geotechnical laboratory of the University of Zielona Góra. All previous studies of the boreholes in Słubice were conducted for engineering geology. It was the reason the samples were described to meet the standard PN-EN ISO 14688 Geotechnical investigation and testing - Identification and classification of soil [31].

To solve the age problem of organic sediments - the chosen sediments were radiocarbon dated using the AMS technique (1.5 SDH-Pelletron Model "Compact Carbon AMS") in Poznan Radiocarbon Laboratory. The procedure of ${ }^{14} \mathrm{C}$ dating of organic material consists of the following stages: chemical pretreatment (acidalkali-acid), production of $\mathrm{CO}_{2}$, graphitisation, ${ }^{14} \mathrm{C}$ measurement and calibration of obtained ${ }^{14} \mathrm{C}$ age $[1,2,12]$. AMS technique allows analysing very small samples $(<1 \mathrm{mg}$ of carbon) [7] which is very important in fluvial deposits which can contain very small amount of carbon.

\section{14C DATING RESULTS}

The profiles of the performed boreholes were found to contain various types of soils (Fig. 4). They contain peats, alluviums, silty clays, medium and coarse sands and gravel. The total largest thickness of the organic sediments (peats and alluvium), where the samples for radiocarbon dating were derived from, occurs in profile Stubice 3 and reaches almost $3 \mathrm{~m}$ (Fig. 4). The smallest thickness was found in profile Stubice 5. In the case of profile Stubice 6, the bottom of organic sediments was not drilled through.

In the discussed area (the Odra river valley), the age of similar, shallow organic sediments is mainly interpreted as Holocene or late Allerød [4]. However, not everywhere (e.g. in Słubice) their age was confirmed. 
Table 1. AMS ${ }^{14} \mathrm{C}$ dating results for organic sediments in Słubice together with calibrated dates (calibration with OxCal v4.2.4 Bronk Ramsey 2013, and IntCal13 atmospheric curve, [35]).

\begin{tabular}{|c|c|c|c|c|c|c|}
\hline $\begin{array}{c}\text { Sample } \\
\text { name }\end{array}$ & Lab. no. & $\begin{array}{c}\text { Profile name } \\
\text { (street) }\end{array}$ & $\begin{array}{c}\text { Localisatio } \\
\text { n of the } \\
\text { sample in } \\
\text { profile } \\
\text { depth in } \\
\text { m) }\end{array}$ & $\begin{array}{c}\text { Type of } \\
\text { soil } \\
\text { according } \\
\text { PN-EN } \\
\text { ISO } \\
14688\end{array}$ & $\begin{array}{c}{ }^{14} \mathrm{C} \text { age } \\
(\mathrm{BP})\end{array}$ & $\begin{array}{c}\text { Cal. Age 95.4\% } \\
\text { conf. intervals } \\
\text { (BC) }\end{array}$ \\
\hline Słubice 1 & Poz-49367 & Niepodległości & 7.0 & peat & $9540 \pm 60$ & $9180-8725$ \\
\hline Słubice 2 & Poz-49368 & Kochanowskiego & 7.0 & $\begin{array}{c}\text { organic } \\
\text { clayey silt }\end{array}$ & $4790 \pm 35$ & $3650-3385$ \\
\hline Słubice 3 & Poz-49369 & Niepodległości 2 & 6.0 & peat & $9310 \pm 60$ & $8725-8345$ \\
\hline Słubice 4 & Poz-49370 & Wandy & 6.0 & $\begin{array}{c}\text { organic } \\
\text { clayey silt }\end{array}$ & $7620 \pm 60$ & $6600-6390$ \\
\hline Słubice 5 & Poz-49372 & Wawrzyniaka & 5.5 & organic & $7250 \pm 40$ & $6220-6030$ \\
\hline Słubice 6 & Poz-49373 & Chopina & 5.0 & silty clay & $9520 \pm 50$ & $9140-8710$ \\
\hline
\end{tabular}

The results allow to determine the age and to identify all the dated sediments as Holocene (Table 1, Fig. 5). The difference in the age between the particular radiocarbon dates obtained in this investigations amount at $5 \mathrm{ka}$ (samples Stubice 2 and Słubice 6, Table 1, Fig. 5). A precise interpretation of results may be difficult due to the reservoir effect, where the real age of the sample may be different from the radiometric age (e.g. fluvial type sediments) by $\sim 400$ years in the marine environment, and up to 2,000 years in the inland waters environment such as lakes or rivers $[9,38]$. The reservoir age corrections are important issue in many different types of research [27, 29]. In the inland reservoirs, the carbonates which affect water flowing into the reservoir can be the source of that effect. In this case, the close neighbourhood of glacial sediments to the Odra river (Fig. 1 B) may affect to it. Tills, containing $\mathrm{CaCO}_{3}$ (although inconsiderable amounts - several percent) could be the source of $\mathrm{CaCO}_{3}$. However the bed of the Odra River consists of fluvioglacial sands, which cannot be the source of carbonates. Therefore, the reservoir effect seems to be negligible here. Due to this fact, the obtained data referring to the age of the investigated sediments are interpreted cautiously but they confirm the Holocene origin of the sediments. Radiocarbon dating results for chosen six samples of different sediments are presented in Table 1, Fig. 4 and calibrated ${ }^{14} \mathrm{C}$ measurements are shown in a graphical form on Figure 5. 


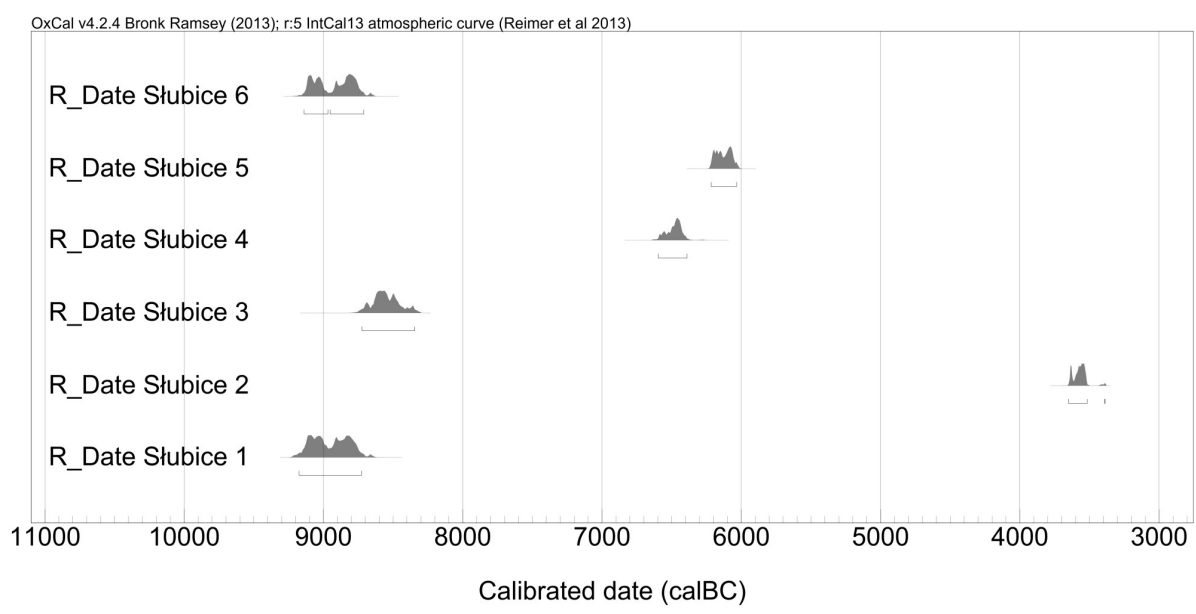

Fig. 5. Calibration in graphical form of the Stubice samples (Calibration program OxCal v4.2.4)

\section{INTERPRETATION AND DISCUSSION OF THE RESULTS}

The analysed sediments are likely to have originated in similar environmental conditions but in a different period of time. In the turn of the Pleistocene and Holocene, braided river valleys in central and western Poland changed their sedimentation style from coarse-grained (sandy-gravelly) aggradation to finer deposition (sandy, silty) due to activity at younger meandering rivers [21]. Organogenic sediments are typical for Holocene. Considering that in Holocene the Odra River meandering was changing its location, the thickness of sediments can be different. In addition, taking into account climatic fluctuations, the flood events [5, 32-34] and the dynamics of the rivers decline in this time, it was possible to create a numerous oxbow lakes. This is why the analysed samples from Stubice, derived from the same depth, represent different time periods. To exemplify the issue it is enough to mention two dated samples: Stubice 2 and Słubice 4, (from the same depth and located next to each other) which are of different age. Their lithology (organic clayey silt and organic silt) suggests the floodplain origin as a result of a long-term sedimentation over a thousands of years. According to Ferguson and Brierley [6] floodplain classification the mentioned sediments can be related to the vertical accretion sandy floodplain or muddy floodplain. Such facies is usually represented by muds, peats and silty and sandy sediments.

In the case of studied sediments (samples Stubice 1, 3 and 6), it may be assumed that they are Preboreal sediments which originated in a cold climate (subarctic) 
(Table 2). However, it should be noticed that in terms of lithology they are different. The sediments of a "silty clay" type (sample Stubice 6), reveal features characteristic for a bimodal age (Fig. 5). However, for establishing approximate age it is not a hindrance. In the case of samples Stubice 1 and 3, the analysed sediment was peat. The sediments of samples Słubice 4 and 5 (organic clayey silt and organic silt) were formed $\sim 2000$ years later in different climate conditions. On the basis of the radiocarbon age, they were identified as Atlantic. The climate was then warmer and moister, like in Preboreal [25, 30, 32-34]. The youngest sample (Stubice 2), indicates Subboreal chronozone, when the climate changed again, was warm and dry $[25,39]$. It is characteristic that the age of the samples do not corresponds to the depth of their location (e.g. sample Stubice 1 versus Słubice 2, and Słubice 5 versus Słubice 6; Figs. 4, 5).

Table 2. Age and chronozones in Holocene in analysed samples in Słubice, Odra river valley (chronozones after Walanus and Nalepka [39] and their age in calibrated years before AD 2000 and BP (after [23, 25, 26, 39]).

\begin{tabular}{|c|c|c|c|c|c|}
\hline $\begin{array}{c}\text { Sample } \\
\text { name }\end{array}$ & $\begin{array}{c}\text { Type of soil } \\
\text { according PN- } \\
\text { EN ISO 14688 }\end{array}$ & $\begin{array}{c}{ }^{14} \text { C age of } \\
\text { samples (BP) }\end{array}$ & $\begin{array}{c}\text { Chronozone } \\
\text { s }\end{array}$ & $\begin{array}{c}\text { Boundaries in } \\
\text { calendar years } \\
\text { before AD 2000 }\end{array}$ & $\begin{array}{c}\text { Boundaries in } \\
\text { conv. } \\
\text { Radiocarbon } \\
\text { vears BP }\end{array}$ \\
\hline Stubice 1 & peat & $9540 \pm 60$ & Preboreal & $10150-11700$ & $9000-10000$ \\
\hline Stubice 2 & $\begin{array}{c}\text { organic clayey } \\
\text { silt }\end{array}$ & $4790 \pm 35$ & Subboreal & $2600-5800$ & $2500-5000$ \\
\hline Słubice 3 & peat & $9310 \pm 60$ & Preboreal & $10150-11700$ & $9000-10000$ \\
\hline Stubice 4 & $\begin{array}{c}\text { organic clayey } \\
\text { silt }\end{array}$ & $7620 \pm 60$ & Atlantic & $5800-8900$ & $5000-8000$ \\
\hline Słubice 5 & organic silt & $7250 \pm 40$ & Atlantic & $5800-8901$ & $5000-8000$ \\
\hline Słubice 6 & silty clay & $9520 \pm 50$ & Preboreal & $10150-11700$ & $9000-10000$ \\
\hline
\end{tabular}

The results obtained in the dating procedure indicate that all the analysed sediments were formed within the last 10,000 years (Tab.1 and 2; Fig. 5). Such a result contradicts the earlier stratigraphic interpretations: 1) it was assumed that a "remnant" in the Odra valley is built out of sediments of Eemian interglacial origin [10]; 2) the possible analogy of sediments occurring within a few dozen kilometres from Stubice (in Radówko), where the age was established as older, than Holocene $[4,37]$. The results of radiocarbon dating are contrary to the interpretation of geotechnical analysis - the values of the preconsolidation ratio [18-20] and to the Gontaszewska [10] previous assumptions. Probably the high value of preconsolidation ratio was not necessarily connected with glaciations in this area but with other environmental changes [13], not considered by Kotowski and Kraiński [20] in their previous investigations. Among the changes in the Holocene environment in central Poland couple fluvial periods and significant 
changes in river system in this area should be mentioned [33, 34] as an influence on the height of this indicator.

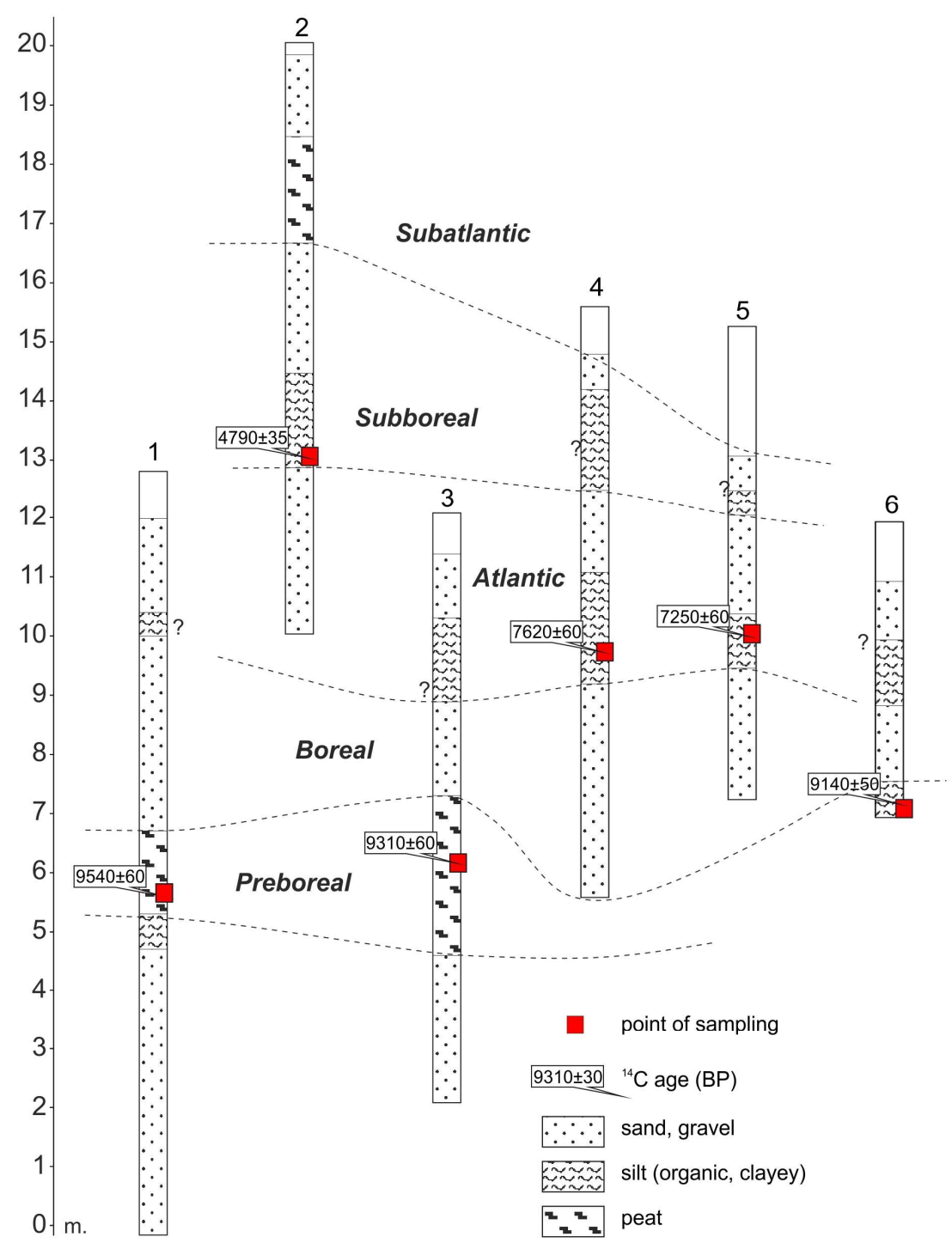

Fig. 6. A proposal of Holocene sediments stratigraphy of the Odra river valley in Stubice (it is assumed that individual layers of sediments do not have continuity in the entire analysed area, which is a results of the variability of the meandering river valley, description of the sediment like in Fig. 4). 
Based on obtained $14 \mathrm{C}$ dating results and high variability of sediments in the riverbed, stratigraphy for the studied layers in this paper was proposed (Fig. 6). The proposal of stratigraphy of sediments from the Słubice region is a research hypothesis which requires further research.

\section{CONCLUSIONS}

Two hypotheses were verified by radiocarbon dating of six different organic samples from different depth in Odra valley. The first hypotheses was that deposits have been mostly interpreted as the Holocene fluvial sediments. However geotechnical studies and values of preconsolidation ratio have questioned Holocene interpretation. That is why another hypotheses presumes an interglacial (possibly Eemian) age of the discussed fluvial/organic sediments. Despite similarities between the organic sediments from the areas of the Odra river valley in the neighbourhood of Frankfurt am Oder and Stubice (similar composition), their radiocarbon ages are different. Similar organic material in the Słubice area interpreted as a Late Glacial or Eemian sediments are of Holocene age. The analysed sediments are the record of intensive accumulation of Odra river channel. The radiocarbon date diversity in the profile at the same depth may be due to the meandering character of the river in the Holocene which migrated on the valley floor. Taking into account climate fluctuation, which intensified in the Holocene and increasing fluvial activity, the increased thickness of river sediments is justified. The attempt to compare the analysed sediments to deposits from the neighbouring areas should be rejected.

The measurement error, bimodality of a part of results (Fig. 5), as well as the reservoir effect of the method do not allow equalizing the age of the mentioned sediments. For sediments from German side, the age (without calibration) may be determined as Allerød interstadial (the end of the last glaciation). The diversity of sediments derived from similar depths in the area of Stubice (ex. in borehole Stubice 1 and Słubice 2 in the same depth - $14 \mathrm{~m}$ a.s.l. there are various sediments differing by almost 5000 years, Fig. 4) makes searching for any similarities to sediments from neighbouring areas useless (also from areas of the Valley of the Odra river on German territory).

\section{ADDITIONAL INFORMATION}

This work was supported by the University of Zielona Góra, Faculty of Civil Engineering, Architecture and Environmental Engineering, Institute of Building Engineering. 
Special thanks to prof. Tomasz Zieliński and dr Danuta Michalska for helpful comments on the first draft of the manuscript.

\section{REFERENCE}

1. Ascough, PL, Bird, MI, Francis, S and Lebl, T 2011. Alkali extraction of archaeological and geological charcoal: evidence for diagenetic degradation and formation of humic acids. Journal of Archaeological Science 38, 69-78.

2. Benysek, M, Michalska, D, Fabisiak, E and Stawikowski, W 2017. Analysis of charcoal and wood from Czarnówko site (Pomerania Region, Poland): 14C dating versus relative chronology show consistent evidence of Wielbark Culture presence. Radiocarbon 59, 1, 45-60.

3. Boulton, GS and Dobbie, KE 1993. Consolidation of sediments by glaciers: relations between sediment geotechnics, soft-bed glacier dynamics and subglacial ground-water flow. Journal of Glaciology 39, 26-44.

4. Brose, F 1988. Geological Processes and its results in Ziltendorf Lowland from Vistula Glaciation. Veröffentlichungen des Museums für Ur- und Frühgeschichte Potsdam 22, 127-134.

5. Büntgen, U et al. J 2011. 2500 Years of European Climate Variability and Human Susceptibility. Science 331, 6017, 578-582.

6. Ferguson, RJ and Brierly, GJ 1999. Downstream changes in valley confinement as a control on floodplain morphology, lower Tuross River, NSW, Australia: a constructivist approach to floodplain analysis. In: Miller, AJ and Gupta, A (eds) Varieties of fluvial Form. Chichester: Wiley, 378-407.

7. Fowler, AJ, Gillespie, R and Hedges, REM 1986. Radiocarbon dating of sediments by accelerator mass spectrometry. Physics of the Earth and Planetary Interiors 44, 15-20.

8. <geoportal.gov.pl>

9. Geyh, MA and Schleicher, H 1990. Absolute Age Determination. Physical and Chemical Dating Methods and Their Application. Berlin Heidelberg: Springer-Verlag.

10. Gontaszewska, A 2010. Origin and geotechnic aspects of organic soils occurace in Odra valley in Stubice (Geneza i geotechniczne aspekty występowania gruntów organicznych $w$ dolinie Odry - przykład Stubic). Górnictwo i Geologia 5, 4, 105-114.

11. Gontaszewska, A 2012. Organic soils in Stubice, Odra river valley (Grunty organiczne na terenie Słubic (dolina Odry)). In: Błaszkiewicz, M and Brose, F (eds) Correlation of Pleistocene sediments on the Polish-German border in the lower Odra valley (Korelacja osadów plejstocenu na pograniczu polskoniemieckim w Dolinie Dolnej Odry). XIX konferencja Stratygrafia plejstocenu Polski. Państwowy Instytut Geologiczny, Cedynia, September, 3- 


\section{7, 61-67.}

12. Goslar, T, Czernik, J and Goslar, E 2004. Low-energy 14C AMS in Poznań Radiocarbon Laboratory, Poland. Nuclear Instruments and Methods in Physics Research B 223, 5-11.

13. Holtz, RD, Kovacs, WD and Sheahan, TC 2011. An introduction to Geotechnical Engineering. Upper Saddle River: Pearson Education.

14. Howard, AD 1992. Modeling channel migration and floodplain sedimentation in Meandering Streams. In: Carling, PA and Petts, GE (eds) Lowland Floodplain Rivers: geomorphological Perspectives. Chichester: Wiley, 1-41.

15. Kalis, AJ, Merkt, J and Wunderlich J 2003. Environmental changes during the Holocene climatic optimum in central Europe - human impact and natural causes. Quaternary Science Reviews 22, 33-79.

16. Keilhack, v.K and Linstow, v.O 1931. Geological map of Prussia and neighboring German countries, explanations to sheet Frankfurt a.Oder (Geologische Karte von Preußen und benachbarten deutschen Ländern, Erläuterungen zu Blatt Frankfurt a.Oder) 1983, 91, Berlin (Preuß. Geol. Landesanstalt).

17. Kotowski, J and Kraiński, A 1989. Glacitectonical disturbances along the Nysa Łużycka and Oder river valley on the Sanice - Kostrzyn section (Zaburzenia glacitektoniczne wzdluż doliny Nysy Łużyckiej i Odry na odcinku Sanice - Kostrzyn). VI Glaciotectonics Symposium, Wyd. Uczelniane WSI, Zielona Góra, 149-157.

18. Kotowski, J and Kraiński, A 2000a. Geologic structure of Oder-Valley in Słubice-city (Budowa geologiczna Doliny Odry w Stubicach). Zeszyty Naukowe Uniwersytetu Zielonogórskiego 121, 61-68.

19. Kotowski, J and Kraiński, A 2000b. Chosen geotechnic problems of Słubicegrounds (Wybrane zagadnienia geotechniczne gruntów ze Stubic). Zeszyty Naukowe Uniwersytetu Zielonogórskiego 121, 77-92.

20. Kotowski, J and Kraiński, A 2000c. Preconsolidation coefficient in organic soils in Słubice-city (Współczynnik prekonsolidacji w gruntach organicznych w Słubicach). Zeszyty Naukowe Uniwersytetu Zielonogórskiego 121, 93-104.

21. Kozarski S., Rotnicki K. 1977. Valley floors and changes of river channel patterns in the North Polish Plain during the Late Würm and Holocene. Quaestiones Geographicale 4, 51-93.

22. Krygowski, B 1961. Physical geography of the Wielkopolska Lowland, Part I. Geomorphology (Geografia fizyczna Niziny wielkopolskiej. Cz. I. Geomorfologia). Poznań: PTPN, Wydział Matematyczno-Przyrodniczy, Komitet Fizjograficzny. 
23. Mangerud, J, Andersen, ST, Berglund, BE and Donner, JJ 1974. Quaternary stratigraphy of Norden, a proposal for terminology and classification. Boreas 3, 109-128.

24. Marks, L 2005. Pleistocene glacial limits in the territory of Poland. Przeglad Geologiczny 53, 988-993.

25. Marks, L 2016. Climate change in the Holocene (Zmiany klimatu w holocenie). Przeglad Geologiczny 64, 59-65.

26. Marks, L, Ber, A and Lindner, L (eds) 2014. Principles of the Polish stratigraphic classification and terminology of the Quaternary (Zasady polskiej klasyfikacji i terminologii stratygraficznej czwartorzędu). Warszawa: Polska Akademia Nauk, Komitet Badań Czwartorzędu.

27. Michalska, D, Pazdur, A, Czernik, J, Szczepaniak, M and Żurakowska, M 2013. Cretaceous aggregate and reservoir effect in dating of binding materials. Geochronometria 40, 1, 33-41.

28. Michczyńska, D, Starkel, L, Nalepka, D and Pazdur, A 2013. Hydrological Changes after the last ice retreat in Northern Poland using radiocarbon dating. Radiocarbon 55, 2-3, 1712-1723.

29. Nawrocka, D, Michniewicz, J, Pawlyta, J and Pazdur, A 2005. Application of radiocarbon method for dating of lime mortars. Geochronometria 24, 109115 .

30. Notebaert, B and Verstraeten, G 2010. Sensitivity of West and Central European river systems to environmental changes during the Holocene: A review. Earth-Science Reviews 103, 163-182.

31. PN-EN ISO 14688 Geotechnical investigation and testing. Identification and classification of soil.

32. Starkel, L, Soja, R and Michczyńska, DJ 2006. Past hydrological events reflected in Holocene history of Polish rivers. Catena 66, 24-33.

33. Starkel, L, Michczyńska, D, Krąpiec, M, Margielewski, W, Nalepka, D and Pazdur, A 2013. Progress in the Holocene chrono-climatostratigraphy of Polish territory. Geochronometria 40, 1, 1-21.

34. Starkel, L, Michczyńska, DJ, Gębica, P, Kiss, T, Panin, A and Persoui, J 2015. Climatic fluctuations reflected in the evolution of fluvial systems of CentralEastern Europe (60-8 ka cal BP). Quaternary International 388, 97-118.

35. Reimer, PJ et al. 2013. IntCal13 and Marine13 radiocarbon age calibration curves 0-50,000 Years cal BP. Radiocarbon 55, 1869-1887.

36. Urbański, K 2005. Geological map explanation of Poland in scale 1:50 000, Słubice sheet 462 (Objaśnienia mapy geologicznej Polski w skali 1: 50 000, arkusz Stubice (462)). Warszawa: Ministerstwo Ochrony Środowiska i Państwowy Instytut Geologiczny.

37. Urbański, K and Winter, H 2005. The Eemian Interglacial in the section Radówek (Łagów lakeland, western Poland) and its implication for till 
lithostratigraphy (Stanowisko interglacjału eemskiego $w$ Radówku (Pojezierze Łagowskie, zachodnia Polska) $i$ jego implikacje dla litostratygrafii glin zwałowych). Przeglad Geologiczny 53, 418-424.

38. Walanus, A and Goslar, $\mathrm{T}$ 2009. Radiocarbon dating (Datowanie radiowęglowe). Kraków: Wydawnictwa $A G H$.

39. Walanus, A and Nalepka, D 2005. Calendar age of boundaries arbitrarily determined in radiocarbon time scale (Wiek rzeczywisty granic chronozon wyznaczonych w latach radioweglowych). Botanical Guidebooks 28, 313321.

40. Zieliński, T 2014. Sedimentology. Rivers and lake deposits (Sedymentologia. Osady rzek i jezior). Poznań: Wydawnictwo Naukowe UAM.

Editor received the manuscript: 29.05.2019 